\title{
Preventing Collapse of Race in Kim
}

\author{
DÁNIEl NyiKos
}

The novel Kim is, perhaps, the most complete elaboration of Kipling's production of colonizing texts. These texts ritualistically open ideological space for the purpose of exposing gaps in colonizing representation, seeking to suture the potential for a breakdown in signification in order to preserve the colonial enterprise to British colonizing subjects. The importance of Kim in Kipling's oeuvre can, perhaps, not be overstated. Its centrality in his writing and especially in his writing about India is summed up by Charles Allen (2007): "Of the fiction, if we exclude his writing for children there are plenty of well-crafted stories but very little that really holds the imagination except in fits and starts, and absolutely nothing of worth linked to India. With Kim he had said it all" (Kindle locations 6201-6202). Kipling wrote Kim after leaving India. It was first published, in serial form, from 1900, and represents the last of Kipling's fiction about India. It might be seen as a culmination, and as such has a unique place in Kipling's oeuvre. Unlike Kipling's previous fictions, Kim is not chiefly addressed to the colonizer in the colony. Eddy Kent (2014) confirms this: "If the short fiction of the 1880s and 1890s addressed the tastes and reading habits of the Anglo-Indians, Kim was written for the empire by a man interested in Britain's place in the world" (142). Thus, Kim plays a central role in locating Kipling's ideology of racial hegemony, in which a white character can experience and enjoy the potential for adopting a multiplicity of ethnic identities without endangering the white identity that bestows this power upon him.

Kim demonstrates that race is not fixed, but reserves the ability to take on new racial signification for the colonizing white characters. This plays a crucial role in the novel, such as in the climax, when the protagonists are separated from the world of familiar signification, only to choose to return to the same regime of truth, cancelling the potential for change and closing the representational gap exposed by the reality of life in the colony. As such, Kim exemplifies the cynical move of demonstrating the limitation of colonizing ideology and then denying the possibility of change, addressed now not only to colonizers with firsthand experience in the colony but to all who could potentially enter that space. Christensen (2012) argues that in Kim "Kipling demonstrates conclusively that a hybrid identity based on the recognition of self-differentiality can, and has, been successfully deployed in the imaginative service of racism and imperial power" (26). Even while demonstrating that racial boundaries can be crossed, the hegemony of whiteness is reified. 
In the text, the racial ideology that is so essential for the colony's existence is presented as absolutely fixed, as characters are endlessly referred to in terms of their race and ethnic identity, which are treated as determining almost every aspect of their identities. The plot of the novel, however, relies on the ability of characters to fool others into reading them as members of other identities. That is to say, the success of each side in the colonial conflict depicted in the novel depends on the ability of agents to successfully adopt the signifiers of other identities. When the colony depends on the perfect separation of colonizer and colonized, "White" and "Black," this fluidity of identity seems to belie both the racial essentialism of the rest of the novel and the ideology at the heart of the empire itself.

The first chapter of Kim depicts a scene that quickly establishes its cynical perspective on British colonial rule through its frank depiction of the successive regimes of imperial control over India as well as the military power required to establish these.

The novel opens with the protagonist, Kimball O'Hara, sitting "astride the gun Zam Zammah" (Kindle location 20). It makes an explicit connection of control of the gun with control of India: "Who hold Zam-Zammah, that 'fire-breathing dragon', hold the Punjab, for that great green-bronze piece is always first of the conqueror's loot. There was some justification for Kim... since the English held the Punjab and Kim was English" (Kindle location 21-22). Kim mocks a Muslim and a Hindu boy in turn who demand he get off the cannon, telling them "All Mussalmans fell off Zam-Zammah long ago!" and "The Hindus fell off Zam-Zammah too. The Mussalmans pushed them off" (Kindle location 64-65). The cynicism of this exchange is particularly driven home by the description of the Hindu boy, as the narrator writes, "His father was worth perhaps half a million sterling, but India is the only democratic land in the world" (Kindle location 65). The suggestion that democracy is not even present in the United Kingdom, of course, draws attention to the absurdity of this claim, as does the situation of the scene: a boy, drawing authority from shared racial identity with the military conquerors of India, establishes his claim on the symbol of control of the city that is, itself, an instrument of war. This model of "democracy," based in race and military supremacy, offers a cynical perspective on the colonizing ideology of the British, suggesting that the only democracy existing in the world is that contained in the most brutally simple arithmetic of soldiers and battlefields. It does not matter which of the children has the most wealth, so long as one is of the race of the colonizers, who control the military. In this, we can see a very model of Foucauldian hegemony in action: Kim enjoys the dominance constructed for him by the signifying system that India is part of. 
Just as it draws back the veil from how the British control India, the first scene illustrates a truth that the British colonizing ideology must suppress: the idea that, in time, the British, too, might "fall off" Zam-Zammah; in other words, that British colonial rule in India might end, and another group might take over. Much of the plot of the novel revolves around the "Great Game," the "Indian Survey Department" acting as a secret service makes moves and counter-moves against both Indians resisting British rule and foreign agents desiring control of India for their own countries. The work of the survey department in combining geography, ethnography, and espionage richly demonstrates how knowledge of the Orient functions in establishing both control and justification for domination. The Colonel explains the work of the agent thus: "I will give thee a hundred rupees for knowledge of what is behind those hills_-for a picture of a river and a little news of what the people say in the villages there" (Kindle location 1709-1710). By engaging in the "Great Game" at all, British agents implicitly acknowledge that there is a chance of one of these forces gaining supremacy: all the parts of India could become no longer subject to British rule. In the novel, the Russian agents fail in their mission because they lack understanding of India. This is the privileged domain of only the British.

It is vital to understanding the role of a text like Kim in shaping and buttressing colonizing ideology, that every move of the "Great Game" is played out with disguise and duplicity, in which control over signification-especially being able to adopt the signifiers of non-white races and ethnic castes - is key to success. Bhabha (1994) demonstrates the importance of the stereotype to the subjectification of both colonizer and colonized. As he writes, "The stereotype... is a simplification because it is an arrested, fixed form of representation that, in denying the play of difference..., constitutes a problem for the representation of the subject in significance of psychic and social relations" (75, emphasis in original). As he shows, the stereotype is not incorrect so much as fixed, lacking in the nuance and capacity for change that all representation contains. To create a disguise to alter what one is signified as, is to acknowledge that race is constructed and that signification is malleable, even to the point that one person can be signified as different identities, when of course the very stability and permanence of race are essential to the racist hierarchy on which the represented superiority of the British colonizer depends.

It is important at this point to also acknowledge the anxiety-producing potential that the free adoption of non-white identities opens: the threat that a person of colour could adopt a white identity. As has been discussed, if the colonized were to be able to erase the markers of difference in signification and become the colonizer, this would lead to the complete collapse of the colony and of white identity. This is the threat that the text must contain. 
In marked contrast to the suggestions of racial mutability opened by the events Kim experiences, the novel's narrator employs a very deterministic representation of race, insisting that characters' behaviour and attitudes are shaped by their racial identities. In doing so, the novel creates a nominal separation in race that it represents as visible, permanent. and essential. One example for this is in the narrator's description of Kim's fear of the snake he and the lama encounter in a farmer's field. While the lama responds with peace, Kim's response, according to the narrator, is determined by his race: "II hate all snakes,' said Kim. No native training can quench the white man's horror of the Serpent" (Kindle location 632-633). The novel has countless examples of this racial essentialism delineating and determining the behaviours of non-white characters, and it is important to note how many times it does the same for white characters. This appears to firmly fix the racial signification that white supremacy depends on.

Kim's whiteness becomes a point of discussion at several points in the novel. The phrase "a Sahib and the son of a Sahib" is used to describe him four times in the novel. Its final use is by Kim himself, who uses it to describe his own positionality. Hubel (2004) stresses that "Kim assures those readers that Kim is fully white: the borders that protect white rule haven't been breached" (239). The first time it is employed, the lama uses it to express his shock that Kim could be white; it is Kim's knowledge of India and its people that the lama finds difficult to correlate: "A Sahib and the son of a Sahib-' The lama's voice was harsh with pain. 'But no white man knows the land and the customs of the land as thou knowest. How comes it this is true?'” (Kindle location 1315-1316). This contrast suggests the difference between colonizing knowledge produced by the ignorant English colonizer and Kim's casual, even playful familiarity with the identities he encounters. Of the novel's construction of the proper English sahib, Hubel notes that "in this vision of imperialism, [...] a Sahib is not always a Sahib and not all Europeans have an equal right to rule" (235). Kim must learn, through his experiences in the novel, the right way to employ his whiteness and the privileged access to knowledge of India that it brings.

Despite the lama's surprise, Kim's knowledge of India echoes the colonizing knowledge used by the British to establish and justify their control over the colonized space. Kim's experience growing up on the street has given him a familiarity with the place that he exploits throughout the novel, whether cheating ticket sellers or knowing how to flatter potential donors for the lama. He demonstrates the ability of the Englishmen he is with to control signification, even his own. He describes himself as though there were no difference between him and the colonized. He tells the lama, "I am not a Sahib. I am thy chela" (Kindle location 3915). By defining himself in his relationship with the colonized rather than acknowledging 
his privileged position as a white Englishman, he uses his connection and service to the colonized as justification for his presence, echoing the Victorian ideal of the altruistic colonizer. According to Hubel (2004), Kim reflects the English colonizer's attempt to claim Indian identity and thus to totalize their power over and access to India. According to her, "Kim is Kipling's one attempt to cross the racial boundary between the Indian and the British and envision an Indian identity for the white person" (248).

Kim himself doubts that his racial identity is fixed and essentialized. When Kim is asked what the English will do, he replies, "Make me a Sahib - so they think" (Kindle location 1345). In his doubt is the budding of his cynicism, in which two possible meanings can be read which both contribute to this cynicism. He acknowledges the impossibility, in this representative system, of creating an identity that should nominally be fixed by the circumstances of birth. If it is possible to "make" a Sahib, then it is also possible that someone born to that role might not become one, which belies the entire system of racial essentialism. He also suggests that they might fail, and he might not become a "Sahib" as defined by their system after all.

The scene on the train shows how each ethnic and gender role is played, as each character described falls into a separate identity, whose interplay becomes the basis of a series of interactions that take on an ethnographic cast. As such, they recall arguments made by Young (1995) and Fabian (1983) about the use of rational science to create the narrative of racial separation. The character includes a Sikh artisan, a "Hindu Jat" and his wife, "an Amritzar courtesan," "a fat Hindu money-lender," and "a young Dogra soldier going home on leave” (Kindle location 405, 406, 408). An excellent example of the anthropological quality of their conversation is in their discussion of the service of soldiers of different castes, in which each character expresses their caste's ostensible opinion of the other castes, seemingly in turn. The conversation serves to illustrate and thus establish the narrator's complete and academic knowledge of India and its people, playing the role of the colonizing text purporting totalizing knowledge, and it also plays out the separation of identities, as discussed.

Building on the effect of the carnival, the potential of change in the novel is represented beside the impossibility of it. The idea of a fixed race determined by racial essentialism is key to the identity of the colonizer. Bhabha (1994) employs Freud and Fanon to demonstrate how the stereotype functions as a fetish, covering up the clear limitations of the idea of the single race. He argues that stereotype functions as part of the timelessness and separateness of the colony, to defuse the anxiety of the colonizer. In Bhabha's words, "The fetish or stereotype gives access to an 'identity' which is predicated as much on mastery and pleasure as it is on anxiety and 
defence, for it is a form of multiple and contradictory belief in its recognition of difference and disavowal of it" (75). Thus, the subject is pushed towards embracing an activity contrary to their stated values, turning on axes of anxiety and mastery together. The colonizer at once recognizes the limitation of their racial imagination and buries it.

As has been shown, identity in Kim is repeatedly represented as fixed, visible, and essentialist; however, one of the major themes of the novel is the ability to alter how one signifies one's subject position, even to the point of adopting other identities. When asked about his own race, Kim casts doubt on a white priest's, Father Victor's, belief in the permanence of race: "He thinks that once a Sahib is always a Sahib" (Kindle location 1281). Characters adopt the costumes of different identities and play the part to varying degrees of skill, some perfectly, suggesting that not only can identity be altered but that one subject position can be performed perfectly by one whose own background should not, in contemporary racial theory, allow them to do so. The lama expresses this mutability of identity when describing the identities he has encountered Kim in: "As a boy in the dress of white men - when I first went to the Wonder House. And a second time thou wast a Hindu. What shall the third incarnation be?" (Kindle locations 1317-1318). Kim's own racial identity appears mutable, and the way India is represented in his eyes shifts depending on how he sees himself. Sullivan (1993) explains how Kim's relationship with India depends on his own understanding of his race:

Kim's numinous celebration of his journey on the multicolored, musical and jewelled Grand Trunk Road, "broad, smiling river of life," for instance, is made possible by his chosen, temporary identity as Indian and beloved "chela" (disciple) to his lama; but that position is later reversed by his confirmed identity as an Englishman whose "fettered soul" will see only a "great, grey, formless India." These contradictory images of shifting identities that construct different Indias are repeated in a series of other historically inscribed contradictions, chief among which are Kim's desire to be loved by India as "little friend of all the World" and to be its master-sahib-imperialist. (11-12)

This relationship demonstrates both the changeability of racial identity and, paradoxically, suggests that this identity, while potentially self-defined, is just as essentializing as the set racial identity defined earlier.

One of the clearest examples of the shifting of race is the incident on the train when an agent of the "Indian Survey Department," fleeing from those who have discovered him, reveals himself to Kim. The agent's identity is represented even by the narrator as being one with how he signifies himself. The narrator calls him "the 
Mahratta" after he enters the car and is taken for one by Kim: "a Mahratta, so far as Kim could judge by the cock of the tight turban" (Kindle location 2868-2869). Because this is the way Kim reads him, it is the way the narrator names him, even after he reveals himself. The man's comment about his means of putting on an identity also reveals the fundamental connection between representation, cynicism, and violence. When Kim urges him to turn to the government for help, the man replies, "We of the Game are beyond protection. If we die, we die. Our names are blotted from the book. That is all" (Kindle location 2902). In this statement, the agent called E.23 pairs a cynical acceptance of the violence of the Great Game with an explicit connection of existence to representation: death, to an agent of the "Indian Survey Department," is no different from being removed from a list of names in a written text. In a list of names of the living from which the names of the dead are removed, there is a tangible demonstration of the controlling and totalizing power of colonial texts of knowledge of the Orient as Said spoke of them. The book, no doubt on the desk of some white official in a governmental office, both records information about and shapes human life itself in the colony.

Immediately afterwards, the agent explains that he was able to "change his face" and thus assume another identity. He says, "At Bandakui, where lives one of Us, I thought to slip the scent by changing my face, and so made me a Mahratta" (Kindle location 2903). As mentioned, the fact that a subject crafted his own position (made himself a Mahratta) and this is echoed by the narrator, who refers to him as "the Mahratta," reveals the success of this moment of self-creation. By saying that changing his face made him something else, he explicitly connects appearance with signified identity. By successfully representing himself with the visual markers of identity, most of all race, he is able to make himself something else. Kim expresses this basic contradiction in his own words thus: "I do not understand how he can wear many dresses and talk many tongues" (Kindle location 2308-2309). As Bhabha's (1994) theory of hybridity reminds us, the very possibility of this undermines not only the ideological basis of colonization but English identity itself, which relies fundamentally on the constructed separation of races. In the demonstration of cultural difference, what is represented as past and present meet, which "undermines our sense of the homogenizing effects of cultural symbols and icons, by questioning our sense of the authority of cultural synthesis in general" (35). Multiplicity of cultures, all of which are accessible, threaten the sense of one superior culture that can make all others like itself.

The idea that blotting a number from a book signifies the death of a British agent further underscores how this play of putting on and taking off identities destabilizes the representation of self and subjecthood in Kim. A number in a book is, perhaps, the most stripped of identity any individual can be, signified only by 
an arbitrary signifier which in itself denotes only pure difference from other subjects. The number, after all, says only that the described entity is neither the thing before it or after it, separated only by this very act of separation. Thus, the roster book establishes itself as the ultimate authority of difference and fixes the agent in relation to its own function in controlling British power in India.

Like E.23, Hurree Chunder Mookherjee is described by a colonizer, Lurgan Sahib, as nameless. Lurgan Sahib tells Kim, "He is a writer of tales for a certain Colonel. His honour is great only in Simla, and it is noticeable that he has no name, but only a number and a letter - that is a custom among us" (Kindle location 2309-2310). While the events of the rest of the novel reveals that "Hurree Babu" does have a name, Lurgan Sahib's description stresses that his name is separate from his subject position in the eyes of the colonizing power. In the fight over the control of the colonized space of India, the individual subjecthood of the colonized is irrelevant.

In fact, to give a name might even hamper the function of an agent, as to confer any form of representation to an agent would be to acknowledge their place within the racialized system constructed by the Europeans and thus make them subject to the fixity of race that that system demands. The number and letter-and nothing else-open the possibility for change, as a number and letter can be assigned to anyone, regardless of race, gender, age, or social status, and can represent with equal power any different point of positionality in those areas of representation. In this, the novel recognizes the limitation of racialized representation and affirms the vital importance of its maintenance.

The fact that never in Kim does a person of colour play a white role demonstrates in this absence just how dangerous to imperialist ideology the revelation about the permeability of constructed boundaries in Kim is. Even amidst all the changing of costumes and painting of skin, which sees Kim take on the identity of an Indian, there is no movement in the opposite direction. While the novel opens the space for this possibility by demonstrating the potential for crossing all other boundaries of identity, never does it suggest the most destabilizing act that this could lead to. Christensen (2012) notes that "the limitations of essentialist notions of identity are projected onto racial others, while the freedom of self-creation derived from a performative notion of identity becomes the exclusive privilege of whites" (10). That the boundary between races is permeable only from the side of the privileged colonizer.

As has been demonstrated, the justification for the British Empire required a racial hierarchy that would have been torn up root and branch were it possible for a colonized subject to be successfully represented as a colonizer. This potential opening of the gap in colonial ideology is not explored on the page even in a colonizing 
text setting up an ideological position for the reader to be able to effectively take in the colony. The changing of one identity for another demonstrates that identity itself is constructed and permeable, though each is required to be unchanging for the ideology of the colony to work. This opens the potential for a breach in the system of signification upon which the colony is based, one which must be controlled.

The final scenes take place where the border between the British Empire and the uncolonized space that lies beyond is unclear. It is partially to map and thus define this space, to fill in this terra incognita on European charts, that the characters come there. In this space between empires where a border prince threatens rebellion against the British Empire, the potential for the destabilization of the colonial system is particularly high. Corinne Fowler (2007) shows how this space is used as a threat to colonial stability, writing that "[i]n Kim at least, merely stepping across the border entails entering a space where Afghans habitually, and with a quiet conscience, violate all that British colonials apparently hold sacrosanct" (58). By sending its agents, including Kim, there to stop the activities of a French and Russian foreign agent, the British intelligence service simultaneously inserts them into a zone of undefined identity and a place where that identity must be particularly shored up and fixed. It is here, amidst the violence and chaos created by the function of the borderland, that the lama achieves the goal he has sought from the start of the novel, to find the river which brings him to enlightenment.

Victor Turner (1990) examines this liminal zone and its possibilities in challenging and simultaneously reifying representational systems. As he describes, the liminal space of ritual and drama — and, it might be added, literature as well—creates a possibility for change and renewal, breaking from familiar norms and constancy. He writes that

[1]iminality can perhaps be described as a fructile chaos, a fertile nothingness, a storehouse of possibilities, not by any means a random assemblage but a striving after new forms and structure, a gestation process, a fetation of modes appropriate to and anticipating postliminal existence. (12)

Thus, the function of the text itself doubles the function of the space beyond the border of the Empire. In both, action takes place outside the limit of the laws, and the breach is simultaneously a trauma and a potential for change and redress. It is a trauma, as Bényei (2011) explains, because it forces the white individual to come into contact with the forces that constitute its subject position, those of intersubjectivity with the Other. It opens the possibility for redress, as previously noted, as part of the human encounter, demonstrating the violence at the heart of 
the colony. Thus, moving outside the Empire and its representational system opens the potential for either the dissolution of the self and the Empire itself.

This potential, later, is not only contained but redirected. Rather than changing the colonial system, the subject-in both text and the reader-is reincorporated into the regime of truth. Recognizing the damage caused by the subject's own actions goes on to shift one's beliefs, a movement echoed by the ideological work Kim performs on its reader. Thus, the novel represents the crisis of a white subject when experiencing the margin of a colonized space, an area that is nominally subject to the British Empire's regime of truth but also falls partially outside this control. The potential for a breach of that system of signification must be controlled.

Kim and the lama come through this experience in the liminal zone with their identities scrubbed clean of signification. Kim experiences this as a crisis of identity, questioning his own role in the colonizing enterprise as well as his entire selfhood. During the violent exchange between the British and the Russian agents, the lama is badly injured, and Kim carries him away and finishes the mission successfully. Left in the village and recuperating along with his master, Kim reflects that his next step would be to leave this idyllic place where the power of the British Empire is not felt.

The failure of British colonial power in this place is demonstrated through the woman at whose house he is staying. She expresses that she has met only one white man before, who said he would return to her and never did, suggesting the promise of progress the self-proclaimed virtuous colonizer makes to the colonized. It is telling, therefore, that the man never returned, neither to prove that what he represented as true- - his promise-was accurate nor to symbolically return her to a place in the symbolic order of the Empire. If she is Lispeth from the short story of the same name, as the details of her life suggest, this further adds to the cynical positioning of her role: wronged by the racial hierarchy of British India, she nevertheless provides unquestioning aid to Kim. Likewise, her own position as neither colonized nor colonizing, as discussed earlier, further deepens the liminal nature of the space Kim finds himself at the moment of the undoing of his subjecthood. In this peaceful place, Kim thinks with regret, "I must get into the world again" (Kindle location 4084). To return "into the world"-the white-represented space in this case is represented as the entire world itself — would be to return to a place where separations are easy and clear, unchallenged by the destabilizing effect of the border zone. However, he does not go immediately.

Instead, Kim falls into self-doubt, repeating to himself his own name, become strange to him. In this border place, he faces his own self, come back strangely to him, echoing the "existentialist agony that emerges when you look perilously through a glass darkly" (Bhabha 1994, 48). Kim seems to have lost his ability to 
make meaning at all, looking at things as though he had no context to assign them signification. The narrator writes that he looks with "strange eyes unable to take up the size and proportion and use of things" (Kindle location 4090). He is unable to represent even his own thoughts, and has become a stranger to himself as well as to the most simple things around himself: "All that while he felt, though he could not put it into words, that his soul was out of gear with its surroundings - a cog-wheel unconnected with any machinery" (Kindle location 4090-4091). Interestingly, in the metaphor of the unconnected cog-wheel, there is the suggestion that Kim has not ceased to be potentially a part of a machine, but rather that the machine he properly fits is somewhere else. It is his context that is wrong, not Kim himself, who is out of place in a way that is simultaneously and equivalently geographical and ideological, removed spatially and mentally from the representational system that had previously given him meaning.

Thus, Kim ends up questioning even his own name and identity: he thinks "II am Kim. I am Kim. And what is Kim?' His soul repeated it again and again” (Kindle location 4093-4094). As also occurs in The Man Who Would Be King, the English colonizer, having been exposed to a world in which the hard representational barriers constructed by the colonial system do not exist, faces a breakdown in his own identity. Kim has appeared to shift identities, and he is able to do so as long as he knows he does it for a power that understands the rules of the Great Game, a game he himself only vaguely guesses at even at the end of the novel.

The question Kim asks at the end of the novel as he experiences his semiotic break is precisely the same he asks earlier, when he is told that he is white and must be trained to be a Sahib.

'Hai mai! I go from one place to another as it might be a kickball. It is my Kismet. No man can escape his Kismet. But I am to pray to Bibi Miriam, and I am a Sahib.' He looked at his boots ruefully. 'No; I am Kim. This is the great world, and I am only Kim. Who is Kim?' He considered his own identity, a thing he had never done before, till his head swam. He was one insignificant person in all this roaring whirl of India, going southward to he knew not what fate. (Kindle location 1696-1699)

For Kim, it is enough to misattribute the source of his distress at encountering the fluidity of his identity to the general confusion that is, to his mind, India. By ascribing his feelings to the colonized space itself, which, as has been shown, is represented throughout the book as unchanging and unchangeable, Kim is able to open himself to accepting without further threat the identity offered to him. At this point, his question is answered by the Colonel, who gives him work spying for 
the British as part of the Survey. Having been invested with a subject position by the representative of the colonizing power, Kim is able to keep this anxiety at bay. It is only when he moved beyond that imperial power that he comes to a crisis.

Kim does not understand the mechanisms of this signifying system. It is when he is removed from that system, finding himself in a place where the color of his skin makes no difference, that the threat of dissolution that has followed him comes to bear. Thus, the anxiety that emerged from the colonial encounter is shown to result from a function of the space itself. Kim, physically exhausted and overwhelmed by the fight with the Russian agents, finds himself coming apart on the borders of the Empire.

Yet Kim's potential to take on multiple ethnic identities and clear enjoyment of it is rooted in a subject position that he never truly loses, for it is the thing that allows him to adopt these different significations. As Christensen (2012) demonstrates, "Rather than fixing Kim's identity within ethnic boundaries, or even multiple ethnic boundaries, the statement 'thou art a Sahib' apparently opens up endless possibilities. To be a Sahib is to be irreducible to any ethnic identity, or even any list of ethnic identities" (25). Thus, the gap in colonial representation is closed by power. Race is demonstrated to be mutable, but only to the colonizer, and the colonizer, even while shifting identities, remains ever the sahib.

Kim returns to himself through an expression of the anxiety and pain that this moment creates for him. The thing that brings Kim back to himself is crying, though he himself does not understand why he cries. As he expresses the trauma of the recognition this moment creates in him, he is pushed back into the system of signification that creates that trauma in him:

He did not want to cry - had never felt less like crying in his life- but of a sudden easy, stupid tears trickled down his nose, and with an almost audible click he felt the wheels of his being lock up anew on the world without. Things that rode meaningless on the eyeball an instant before slid into proper proportion. Roads were meant to be walked upon, houses to be lived in, cattle to be driven, fields to be tilled, and men and women to be talked to. (Kindle location 4094-4097).

The colonizer, glimpsing that the system is flawed and damaging, embraces it and the privilege it grants him. Kim signifies everything exactly as he did before his experience on the edge of the empire, re-establishing the same meanings. As Sullivan (1993) points out, the ideologies of the novel "draw Kim away from the margins and return him to the centers of imperial surveillance and power as a spy" (26). It is particularly significant that he does so according to himself, using his 
own positionality as a starting point from which to define everything else around him: "They were all real and true — solidly planted upon the feet - perfectly comprehensible - clay of his clay, neither more nor less" (Kindle location 4097-4098). Hagiioannu shows that he does this through deploying the European knowledge that plays such a key role in imperialism, as "Kim reasserts his 'Anglo-Irish' self by sheer force of will, and, in a gesture that seems to reassert the dependability of European knowledge and learning, seeks refuge in the mental recitation of the multiplication table in English" (31). He returns unchanged to the representational system he left even though, as has been shown, this system is that which creates the oppressive regime of the colony, which embeds hierarchical identities in every subject it creates. Kim has found that the identity the system grants him uniquely allows him the pleasure of adopting any of those ethnicities without abandoning the power of abandoning his own.

Sullivan demonstrates this ideological contradiction at the end of the novel, pointing out that Kim's return as a reborn colonizer is "a colonial fantasy that suggests an impossible origin for a new colonialist, one with a split sense of the constitution of self, who disavows difference from the native, yet knows otherwise" (177). Kim knows that an oppressive colonial relationship exists in which his positioning is that of the colonizer, though he continues to claim kinship with the colonized. It is through this kinship that he gains legitimacy, as it connects him with India and with those that, as an Englishman, he is in a position of rulership over.

Kim's movement out of and then back into the colonial system of meaning is contrasted in the novel against the lama's attaining of and then giving up of enlightenment. When the lama achieves his quest of finding enlightenment, it is described in explicit terms of breaking free from the system of difference that defines human thought. The lama describes this as finding freedom from "the Wheel of Things," a freedom that separates him from the regime of truth that constructs all knowledge, even from the first moments of awareness in which the self is separated from the Other. He describes the movement of his Soul beyond all things: "By this I knew the Soul had passed beyond the illusion of Time and Space and of Things. By this I knew that I was free" (Kindle location 4178-4179). The closer the lama's soul approaches to the Great Soul, the more his connection to all other things seems to fade, until he becomes one with all things, eternal: "Then my Soul was all alone, and I saw nothing, for I was all things, having reached the Great Soul. And I meditated a thousand thousand years, passionless, well aware of the Causes of all Things" (Kindle location 4181-4182). At this moment, he has become removed completely from the systems of language and meaning-making that define his life, to the point that speaking of his awareness or consciousness is even inaccurate, because even this has been belied by his removal. 
The lama's experience seems to be phrased in terms of escape from the system of différance as described by Derrida, in which the very essence of Being and meaning is based in the complex construction of what Derrida (1982) calls "the play of the trace," which predates Being. As Derrida describes it, différance "can be called the play of trace. The play of a trace which no longer belongs to the horizon of Being, but whose play transports and encloses the meaning of Being: the play of the trace, or the différance, which has no meaning and is not" (22). The lama experiences a state removed from even this "play of trace," in which nothing is differentiated and everything is actually pure Being. As has been discussed, the fundamental grounds of colonial philosophy is the separation of races from each other: thus, the lama choosing to return to the world as it is simultaneously chooses to reintegrate himself into that system.

The lama chooses to return from enlightenment for the sake of Kim, whom he loves. In his description, he does this because he fears Kim will lose himself rather than remain on the path to good: "Then a voice cried: 'What shall come to the boy if thou art dead?' and I was shaken back and forth in myself with pity for thee; and I said: 'I will return to my chela, lest he miss the Way' (Kindle Location 41824183). It is not Kim's body that the lama worries about but his soul; he believes that only through his guidance can Kim eventually "gain merit." Thus, the novel not only suggests that the experience of the Other and the colonized space serves as a means to moral improvement for the white colonizer, but also presents that to serve as a means for this can be the most important motivation of a colonized subject. As such, the relationship between colonizer and colonized is shown to be the most defining system of difference in the novel.

The way the lama returns to his own body reflects the process by which the signifying system is re-established in him, mirroring the universal way the self is separated from what becomes signified as the Other, the world outside the self: "Upon this my Soul, which is the Soul of Teshoo Lama, withdrew itself from the Great Soul with strivings and yearnings and retchings and agonies not to be told" (Kindle location 4183-4184). The retchings and agonies are particularly interesting as they reflect Kristeva's (1982) description of the way the "I" is formed by the violence of expulsion from the body of that which is subsequently not signified as part of the "I": "During that course in which 'I' become, I give birth to myself amid the violence of sobs, of vomit" (3). Through pain and expulsion, the lama returns to himself and the regime of truth he has known all his life, one controlled by and in the service of the white colonizing hegemony.

The process of personal dissolution followed by reincorporation closely follows the anthropological model of the rite of passage first described by van Gennep (1908) and elaborated on by Turner (1967). Turner describes the liminal stage's 
importance in the rite of passage from one status in a community to another, a stage in which "Undoing, dissolution, decomposition are accompanied by processes of growth, transformation, and the reformulation of old elements in new patterns" (99). Symbolically in these rituals it is important for the old identity to be removed so that the initiate can take on a new identity. Like Kim and the lama, the initiate loses the signifiers that fix their subject position, becoming no longer one thing and not yet another. Van Gennep (1908) describes initiation rituals of young men in which the subject "is considered dead" and weakened in a way that is "intended to make him lose all recollection of his childhood existence" (75). At the end of the ritual, "he is resurrected and taught how to live, but differently than in childhood" (75). Through this series of acts, the subject dies to one identity and re-enters the signifying system inscribed as another.

The ritual is at once full of potential and threat. This liminal state, as Turner demonstrates, is an intentional crisis of identity and subjecthood. As he writes, "They are at once no longer classified and not yet classified" (96). This status is accompanied by an opening of possibilities and a transgression of boundaries: its purpose is to ease the trauma of change from one status to another, to make possible the violation of boundaries between identities that would normally be taboo. In a later article, Turner (1990) writes that this experience represents "a no-man'sland betwixt-and-between the structural past and the structural future as anticipated by the society's normative control of biological development. It is ritualized in many ways, but very often symbols expressive of ambiguous identity are found cross-culturally" (11). At the end of Kim, the same language of the loss of self and the opening of ambiguity is used, and the ritual connection with the lama's quest for freedom and merit is clear.

The lama's decision to return to Kim and the material world, then, can be interpreted as a failed rite of passage, or, more precisely, a defeated one. Rather than moving from one identity and life stage to another, the lama, like Kim does at the same time, moves into a liminal space and then returns to the same identity he had before. For the space of time in which he divided his sense of self from his body and conscious mind, the lama wins a sense of unmediated and unsignified experience with reality that transcends one of language and ideology; however, in order to be able to communicate this information to Kim, the lama must reincorporate himself into the same system of signification from which he briefly won his freedom. This demonstrates the contradiction of escaping from ideology Derrida demonstrates, in which one must use the very signs of the signifying system in order to attempt to demolish it, making completely escaping from it very problematic. 
The lama attributes his actions to his love for Kim and expresses his hope that, because of his decision not to embrace his freedom yet, he will be able to guide Kim to it as well. Though he knows enlightenment is freedom from attachment, his attachment to Kim - represented clearly as that of the colonized to the colonizer-causes him to call his internalized racism and oppression love. A further source of dissonance is the lama's insistence that Kim needs him, while Kim has demonstrated repeated superior understanding of circumstances and ability to gain the advantage over others, mirroring the frequent representation of the relationship of colonizer and colonized as being that between parent and child. Landry and Rooney (2010) argue that "the lama seems to signify that which Kim is supposed to leave behind or, at least, separate himself from" (63). In this final scene, Kim distances himself from the figure who has been his father and mother, thus ending a relationship contradictory to his intended role as colonizing patriarch.

There is an interesting note about this final exchange that casts a shadow of complication on the idea that the breach is closed and the danger of destabilization is averted. At the end of the text, it is not clear whether Kim will continue on his path and become an agent of the British Empire. The lama, who is the last character to speak in the novel, says he will help Kim to the same freedom he has known. "'Son of my Soul, I have wrenched my Soul back from the Threshold of Freedom to free thee from all sin — as I am free, and sinless! Just is the Wheel! Certain is our deliverance! Come!' He crossed his hands on his lap and smiled, as a man may who has won salvation for himself and his beloved" (Kindle location 4195-4197). If, as I have suggested, freedom in Kim is represented as freedom from the signifying system upon which the British Empire's system of racial hierarchy is based, then the lama suggests that he might yet be able to help Kim achieve this and remove himself. Salvation, in this case, would be salvation from the limitation and control placed on them by the imperial system, which forces them into certain prescribed roles.

If truly freedom from the signifying system of the colony is thus made possible, it suggests Kim will not only stop being an agent of the British, he will also shed his sense of self. Since identity is mutable and dependent on one's exterior and actions, his whiteness could also be abandoned. In order for him to find the same enlightenment the lama has, it would have to be. The one element standing in contrast to this reading is, however, the essentialism described above: if the qualities of whiteness come out in Kim without ever having been taught or even represented to him, race can never really change. Thus, any fear of destabilization of the racial system of the colony is contained in the fictional separation of races in the novel. Zohreh T. Sullivan agrees that at the end of the novel Kim is implied to embrace his future in the Civil Service, explaining that "this end is also a beginning, or 
rather a colonial fantasy that suggests an impossible origin for a new colonialist, one with a split sense of the constitution of self, who disavows difference from the native, yet knows otherwise" (177). Kim's experiences have served to make him a better colonizer.

At the end of $\mathrm{Kim}$, the colonized and the colonizer return to the system of meaning that signifies them as such. The novel ends with an ostensible gesture of love that is also a gesture to a basic and cynical truth: that, for the sake of the colonizing system, one must learn to privilege the ideal of racial separation and superiority over experiences that suggest the opposite. At the end of the novel, even the colonized subject learns to embrace their position, as the lama chooses to return to the signifying system of the colony after having left it, doing so out of love for a white boy and the regime of truth that he serves as an agent of the British Empire. Kim himself, having experienced and experimented with the capacity for altering his racial identity, has gained knowledge that will be valuable to him in fully embracing the waiting role of white sahib.

\section{Works Cited}

Allen, Charles. 2007. Kipling Sahib: India and the Making of Rudyard Kipling. London: Abacus.

Bényei Tamás. 2011. Traumatikus találkozások: Elméleti és gyarmati variációk az interszubjektivitás témájára. Debrecen: Debrecen UP.

Bhabha, Homi K. 1994. The Location of Culture. London: Routledge.

Christensen, Tim. 2012. "The Unbearable Whiteness of Being: Misrecognition, Pleasure, and White Identity in Kipling's Kim.” College Literature 39 (2): 9-30. https://doi.org/10.1353/lit.2012.0014

Derrida, Jacques. 1982. Margins of Philosophy. Translated by Alan Bass. Chicago: Chicago UP.

Fabian, Johannes. 1983/2014. Time and the Other: How Anthropology Makes Its Object. New York: Columbia UP.

Fowler, Corinne. 2007. Chasing Tales: Travel Writing, Journalism, and the History of British Ideas about Afghanistan. Amsterdam: Rodopi. 
Hagiioannu, Andrew. 2003. The Man Who Would Be Kipling: The Colonial Fiction and Frontiers of Exile. New York: Palgrave Macmillan. https://doi. org/10.1057/9780230287815

Hubel, Teresa. 2004. "In Search of the British Indian in British India: White Orphans, Kipling's Kim, and Class in Colonial India" Modern Asian Studies 38 (1) 227-251. http://www.jstor.org/stable/3876501. https://doi.org/10.1017/ $\underline{\text { S0026749X04001064 }}$

Kipling, Rudyard. 1901/2009. Kim. Urbana, Illinois: Project Gutenberg. Retrieved March 20, 2018 from http://www.gutenberg.org/ ebooks/2226.

Kent, Eddy. 2014. Corporate Character: Representing Imperial Power in British India, 1786-1901. Toronto: University of Toronto Press. https://doi. org/10.3138/9781442617018

Kristeva, Julia. 1982. Powers of Horror: An Essay on Abjection. Translated by Leon S. Roudiez. New York: Columbia UP.

Landry, Donna, and Caroline Rooney. 2010. “Empire's Children.” In Kipling and Beyond: Patriotism, Globalisation and Postcolonialism, edited by Caroline Rooney and Kaori Nagai. London: Palgrave Macmillan. https://doi. org/10.1057/9780230290471 4

Sullivan, Zohreh T. 1993. Narratives of Empire: The Fictions of Rudyard Kipling. Cambridge: Cambridge University Press. https://doi.org/10.1017/ CBO9780511519246

Turner, Victor. 1990. "Are There Universals of Performance in Myth, Ritual and Drama?" in By Means of Performance: Intercultural Studies of Theatre and Ritual. Eds. Richard Schechner and Willa Appel. Cambridge: Cambridge UP.

Turner, Victor. 1967. The Forest of Symbols: Aspects of Ndembu Ritual. Ithaca: Cornell UP.

van Gennep, Arnold. 1908. The Rites of Passage. Translated by Monika B. Vizedom and Gabrielle L. Caffee. Chicago: U of Chicago P.

Young, Robert J. 1995. Colonial Desire: Hybridity in Theory, Culture, and Race. Routledge: London. 